\title{
Access to citizenship for aliens in the Netherlands
}

Citation for published version (APA):

de Groot, G. R. (2001). Access to citizenship for aliens in the Netherlands. In A. Kondo (Ed.), Citizenship in a global world; comparing citizenship rights for aliens (pp. 31-46). Palgrave.

https://doi.org/10.1057/9780333993880_3

Document status and date:

Published: 01/01/2001

DOI:

10.1057/9780333993880_3

Document Version:

Publisher's PDF, also known as Version of record

\section{Please check the document version of this publication:}

- A submitted manuscript is the version of the article upon submission and before peer-review. There can be important differences between the submitted version and the official published version of record.

People interested in the research are advised to contact the author for the final version of the publication, or visit the DOI to the publisher's website.

- The final author version and the galley proof are versions of the publication after peer review.

- The final published version features the final layout of the paper including the volume, issue and page numbers.

Link to publication

\footnotetext{
General rights rights.

- You may freely distribute the URL identifying the publication in the public portal. please follow below link for the End User Agreement:

www.umlib.nl/taverne-license

Take down policy

If you believe that this document breaches copyright please contact us at:

repository@maastrichtuniversity.nl

providing details and we will investigate your claim.
}

Copyright and moral rights for the publications made accessible in the public portal are retained by the authors and/or other copyright owners and it is a condition of accessing publications that users recognise and abide by the legal requirements associated with these

- Users may download and print one copy of any publication from the public portal for the purpose of private study or research.

- You may not further distribute the material or use it for any profit-making activity or commercial gain

If the publication is distributed under the terms of Article $25 \mathrm{fa}$ of the Dutch Copyright Act, indicated by the "Taverne" license above, 


\section{2 \\ Access to Citizenship for Aliens in the Netherlands}

Gerard-René de Groot

\section{Introduction}

This paper will deal with the access to citizenship for aliens in the Netherlands. Traditionally the Netherlands are liberal in respect of granting residence rights and finally citizenship to foreigners. Already in the sixteenth century the Republic of the United Netherlands granted residence rights to a large number of Sefardic jews, who had to leave the Iberian Peninsula (Spain and Portugal) because of the measures of persecution undertaken by the Kings of Spain. At the end of the seventeenth century many Huguenots coming from France went to the Netherlands; in the beginning of the eighteenth century a considerable number of Mennonites had to leave Switzerland and went to the Netherlands. During both the seventeenth and eighteenth centuries many migrant workers went to the Netherlands, coming mainly from the different German states. During the same period a lot of Jews from Middle and Eastern Europe arrived in the Netherlands. At the end of the nineteenth century again a considerable number of (Catholic) Germans arrived in the Netherlands as a consequence of the so called 'Kulturkampf' in Germany.

From the end of the sixteenth century the Republic of the United Netherlands built up a colonial empire. All colonies were occupied by England during the Napoleonic Wars. In 1814 only a part of the colonies were given back to the Netherlands: the Netherlands Indies, Suriname and six islands in the Caribbean. Directly after World War II the Netherlands Indies tried to get independence. A new state, Indonesia, was proclaimed. The Netherlands recognised this independence in 1949. Suriname became an independent republic in 1975. The six Caribbean islands (Aruba, Bonaire, Curaçao, Sint Maarten, Sint Eustasius and Saba) 
are still part of the Kingdom of the Netherlands. Aruba is a 'country' within the Kingdom, the other Caribbean islands together form another country: the Netherlands Antilles.

As a consequence of the independence of Indonesia a considerable number of people migrated from Indonesia to the Netherlands during the late 1940s and the 1950s. As a consequence of the independence of Suriname many inhabitants of Suriname settled down in the Netherlands during the months directly before the independence of Suriname on 25 November 1975 . The vast majority of both groups of migrants already possessed nationality of the Netherlands before they came to the European part of the Kingdom. This was mainly the consequence of treaties concluded with the new independent states. With Indonesia the 'Overeenkomst betreffende de toescheiding van staatsburgers tussen het Koninkrijk der Nederlanden en de Republiek der Verenigde Staten van Indonesï̈' (Treaty on the allocation of citizens between the Kingdom of the Netherlands and the Republic of the United States of Indonesia) was concluded in 1949. In 1975 another Convention to allocate citizens was concluded between the Netherlands and Suriname: 'Overeenkomst betreffende de toescheiding van staatsburgers tussen het Koninkrijk der Nederlanden en de Republiek Suriname' (Treaty on the allocation of citizens between the Kingdom of the Netherlands and the Republic of Suriname).

During the 1930s, groups of Germans (mainly of Jewish origin) came to the Netherlands. Some stayed in the country even after the restoration of democracy in Germany. In the sixties and seventies large groups of migrant workers came from the Mediterranean area to the Netherlands. The most important countries of origin were Turkey and Morocco; Spain, Italy, Greece and former Yugoslavia should also be mentioned. Especially since 1985, many migrant workers and their family members have acquired Netherlands nationality by naturalisation.

A considerable number of people have requested asylum in the Netherlands. In recent years, the annual number of asylum seekers was as follows: 1992: 20300; 1993: 35 400; 1994: 52 600; 1995: 29 300; 1996: $22900 ; 1997: 34400$. Only a relatively low percentage of asylum seekers receive official refugee status (between 12 and 15\%), a considerably higher percentage (more than 30\%) receives another status, which allows the persons involved to stay in the Netherlands, at least until they can return to their country without risk for their safety. In 1996, 51464 illegal immigrants had to leave the Netherlands: 16481 of them were asylum seekers, whose requests for asylum were rejected. 


\section{Origin of aliens}

In 1997 the Netherlands had 15600000 inhabitants, 680000 of whom (around $4 \%$ of the population) did not possess Netherlands nationality. Of these aliens living in the Netherlands 126000 were born on Netherlands territory, 149000 in other EU states, 96000 in Morocco, 91000 in Turkey. ${ }^{1}$ The Netherlands have a strong tradition of granting nationality to aliens under liberal conditions, if they apply for naturalisation. Of the total population of the Netherlands, 1434000 (more than $9 \%$ of the population) were born abroad. Although most of them were not of Netherlands origin, the majority possess Netherlands nationality at the moment. To illustrate:

- 175000 persons were born in Indonesia/Netherlands East Indies. Of these persons only 8,000 do not possess Netherlands nationality. The total Indonesian population living in the Netherlands (including Indonesians born in the Netherlands) is also around 8,$000 ;$

- 182000 persons were born in Suriname. Of these persons only $1^{1}$ do not possess Netherlands nationality. The total Surinamese lation living in the Netherlands (including Surinamese borNetherlands) is around 12000 ;

- 128000 persons were born in Germany. Of these persons 48 uvu do not possess Netherlands nationality. The total German population living in the Netherlands (including Germans born in the Netherlands) is around 54000;

- 143000 persons were born in Morocco. Of these persons 97000 do not possess Netherlands nationality. The total Moroccan population, i.e. without Netherlands nationality (comprising Moroccans born in the Netherlands and those born in Morocco) is around 139000 ;

- 169000 persons were born in Turkey. Of these persons 92000 do not possess Netherlands nationality. The total Turkish population living in the Netherlands (including Turks born in the Netherlands) is around 127000 ).

From these numbers it can be concluded that almost 400000 people living in the Netherlands came from the former colonies (Indonesia and Suriname, and also Netherland Antilles and Aruba). A considerably higher number of people are descended from people who were living in the former colonies. Nowadays almost all these people possess Netherlands nationality.

Of the migrant workers who came to the Netherlands some decades ago, a considerable percentage acquired Netherlands nationality by naturalisation or (for the first generation of descendants born in the 
territory of the Netherlands) by lodging a declaration of option (art. 6 sub b Nationality Act). Now the children of these migrant workers are giving birth to children in the Netherlands. If the parents of these children were born when their father or mother was already living in the Netherlands, the now newborn children acquire Netherlands nationality at birth (art. 3 para. 3 Nationality Act).

\section{Constitutional provisions}

Article 2 paragraph 2 of the Constitution of the Netherlands emphasises that the admission of aliens to the Netherlands, their right to stay in the Netherlands, and their expulsion have to be regulated by an act of parliament. Based on this constitutional provision the Vreemdelingenwet (Aliens Act) was enacted. This Aliens Act, however, gives only a framework, which is elaborated in the Vreemdelingenbesluit (Aliens Decree) and the Vreemdelingencirculaire (Guidelines on Aliens).

One might hesitate to say whether the elaboration of the Aliens Act in a Decree and by Guidelines is perfectly in conformity with the Constitution, because the Decree and the Guidelines are definitely not acts of parliament.

The Constitution does not grant specific rights to aliens, but most rights guaranteed in the Constitution are guaranteed for all persons (citizens and other persons living in the Netherlands). Exceptions are articles 3,4 and 19. Article 3 states that all Netherlands nationals shall be equally eligible for appointment to public service. But this does not imply that aliens can not be appointed as officials. Article 4 mentions that every Netherlands national shall have an equal right to elect the members of the general representative bodies and to stand for elections as a member of those bodies, subject to the limitations and exceptions prescribed by act of parliament. But again, this provision does not exclude aliens from participating in some elections.

A further exception is the right on free choice of labour, which is guaranteed in article 19 paragraph 3 for all Netherlands nationals. But it has to be emphasised that this guarantee is a rather weak one for Netherlands nationals as well, because the article makes it possible to restrict this right by or pursuant to an act of parliament.

\section{Nationality and citizenship}

\section{Acquisition and loss of nationality}

The nationality of the Netherlands is regulated by the Kingdom Act of 19 December 1984, which entered into force on 1 January 1985. This act 
replaced the Nationality Act of 12 December 1892. A total revision of the nationality law of the Netherlands was necessary in order to realise equal treatment of men and women in this field of law and to enable the Netherlands to ratify three international treaties: the New York Convention on the reduction of statelessness of 30 August 1961, the Strasbourg Convention on reduction of cases of multiple nationality and military obligations in cases of multiple nationality of 6 May 1963 , and the Bern Agreement on the reduction of the number of cases of statelessness of 13 September 1973.

The Netherlands law of nationality is based on a system of jus sanguinis a patre et a matre. A legitimate child acquires Netherlands nationality if the father or the mother is a Netherlands national at the time of its birth or is a Netherlands national who died before the birth of the child (art. 3 para. 1 Nationality Act 1984). Illegitimate children acquire Netherlands citizenship jus sanguinis if the mother is a Netherlands national (art. 3 para. 1 Nationality Act). If the child is recognised subsequently by a foreigner and therefore acquires another nationality, it retains the Netherlands nationality. If a foreign minor is recognised by a man with Netherlands nationality, the minor acquires Netherlands nationality (art. 4 para. 1 Nationality Act). In this context it is important to stress that in the Netherlands family law the recognition of an illegitimate child by a man is a juridical act. It is not necessary that the man who recognises the child is the biological father of the child. In case of a judicial establishment of paternity of a Netherlands man the foreign child involved acquires Netherlands nationality as well, although this is not expressly mentioned in the Nationality Act. This acquisition is a consequence of the retroactivity (until the moment of birth of the child) of such a judicial establishment of paternity. A minor who is legitimised by a Netherlands national without previous recognition (e.g. in case of letters of legitimisation given by the King) acquires Netherlands nationality as well. Netherlands citizenship can also be acquired by adoption. If a foreign child is adopted pursuant to a judicial decision he acquires Netherlands nationality, provided that the adoptive father or adoptive mother is a Netherlands national on the day that the decision becomes final and that the child is a minor on the day of the decision at first instance (art. 5 Nationality Act).

Netherlands nationality can also be acquired at birth jus soli or jus domicilius. An acquisition which comes close to an acquisition jus soli only applies for foundlings. According to article 3, paragraph 2 of the Nationality Act a foundling shall be deemed to be the child of a Netherlands national if it was found on the territory of the Netherlands, the 
Netherlands Antilles or Aruba or on a ship or aircraft registered in one of these countries. In this case it also obtains Netherlands nationality on the basis of article 3 paragraph 1 of the Act. This presupposition (praesumptio jus sanguinis) is not absolute. If it becomes apparent within five years from the day on which the child was found, that it does not possess Netherlands nationality, but only a foreign nationality by birth, Netherlands nationality will be lost. But in the case of potential statelessness it keeps Netherlands nationality.

Very important for the nationality integration of families of foreign origin living on Netherlands territory is the provision of article 3, paragraph 3 of the Nationality Act:

a child shall be a Netherlands national if it is born to a father or mother who is residing in the Netherlands, the Netherlands Antilles or Aruba at the time of its birth and if this father or mother was born to a mother residing in one of these countries at the moment of the birth of her child.

This is the so-called third-generation rule. The provision of article 3 , paragraph 3 does not contain a strict jus soli-regulation. The provision does not demand that the child was born on Netherlands soil, only that the father or mother resides in the Kingdom. It can therefore be described as an acquisition jus domicilius (i.e. based on 'domicilium' in the continental European sense of habitual residence).

Some categories of foreigners can obtain Netherlands nationality by making a declaration of option. This is the case with aliens, who are of full age and who were born in the Netherlands and had their domicile or habitual residence there since their birth, provided that they have not attained the age of 25 years. Persons born stateless in the Netherlands and with domicile or habitual residence here can acquire Netherlands nationality after a period of three years. Other foreigners can acquire Netherlands nationality by naturalisation, if they fulfil the conditions mentioned in the Nationality Act (articles 8 and 9). In principle an applicant possessing a foreign nationality has to renounce that nationality or has to promise to do that after his naturalisation, unless this cannot reasonably be expected of him (art. 9 para. 1(b)). From 1992 the government tried to abolish the condition of renunciation of a previous nationality, but parliament finally agreed only to increase the number of categories in which a renunciation can not reasonably be expected from the applicant. Between 1992 and 1998 the condition of renunciation of a previous nationality was not applied in practice. Since 1998 
this condition has been reintroduced but with many more exceptions than before 1992 .

Netherlands nationality is lost by a major in the case of voluntary acquisition of a foreign nationality (art. 15 lit. a), by making a declaration of renunciation (art. 15 lit. b), or if he, after coming of age, has his place of residence for a continuous period of ten years outside the Netherlands, the Netherlands Antilles or Aruba, in the country of his birth and of which he is a national as well, other than in the service of the Netherlands, the Netherlands Antilles or Aruba, or of an international organization at which the Kingdom is represented, or as the spouse of a person in such service (art. 15 lit. c Nationality Act). Finally article 15(d) lays down as a ground for the loss of Netherlands nationality the revocation of the decree granting Netherlands nationality. However this may only take place if the person concerned fails, after his naturalisation, to make every effort to divest himself of his original nationality. This article is a sanction against not fulfilling the requirement laid down in article 9 para 1 lit. b. However Netherlands nationality can never be lost on any ground whatsoever if this would lead to statelessness. The grounds for loss of nationality by minors are regulated by article 16 of the Nationality Act. The main principle is that no minor shall lose Netherlands nationality, as long as one parent still possesses Netherlands nationality.

In 1998 a bill amending the Nationality Act was sent to parliament (draft $\mathrm{nr} .25891$ (R 1609)). The bill provides for the abolishment of recognition and legitimation as grounds for acquisition of Netherlands nationality, but the judicial establishment of paternity can cause the acquisition of Netherlands nationality. The bill proposes to introduce more cases where a foreigner can acquire Netherlands nationality by lodging a declaration of option. However the legal construction of the option will be altered as well. Under the law in force a foreigner acquires Netherlands nationality by using his option right immediately, if he fulfils the conditions which give to him the option right involved. In the future Netherlands nationality will be acquired after the confirmation by the competent authorities that the conditions for the option right were fulfilled at the moment of use of the option right.

The bill describes in article 9 para. 3 those cases in which renunciation of a previous nationality is not requested as a condition for naturalisation. What is remarkable, is that according article 15 voluntary acquisition of a foreign nationality is no longer a general ground for loss of citizenship. In some cases a foreign nationality can be acquired without 
losing Netherlands nationality. The bill proposes to introduce a new ground for loss of Netherlands nationality: deprivation of nationality should be made possible in the case of fraudulent conduct or the concealment of any relevant fact during the naturalisation procedure. In such a case deprivation is even possible in cases where statelessness would be the consequence.

\section{'Nationality' and 'citizenship' distinguished}

The legal system of the Netherlands does not distinguish between the concept of 'nationality' (nationaliteit) and the concept of 'citizenship' (burgerschap). Nevertheless the term 'burgerschap' is often used in order to indicate the right to exercise political rights. But it has to be emphasised that in principle every adult who possesses Netherlands nationality also has the right to exercise political rights. Moreover permanent residents can exercise political rights on the municipal level (see below). The word 'burgerschap' is not often used in legal texts, but can often be found in texts written by political scientists.

Following the modification of the EC Treaty by the Maastricht Treaty, publications on European Community law deal with the scope and content of European citizenship (Europees burgerschap) and the rights linked to European citizenship. Because nationals of the Member States of the European Union possess European citizenship (under Article 8 EC Treaty), all nationals of the Netherlands possess the rights linked to European citizenship.

\section{Stateless persons}

The Netherlands ratified the New York Convention on the reduction of statelessness of 30 August $1961^{3}$ and the Bern Agreement on the reduction of the number of cases of statelessness of 13 September $1973 .{ }^{4}$ In order to avoid cases of statelessness article 6(b) Nationality Act 1984 gives an option right to Netherlands nationality to stateless persons born on Netherlands territory after a residence in the Netherlands of at least three years. The granting of Netherlands nationality to those persons immediately at the moment of birth was refused. There were two reasons for this refusal. Some political parties argued that in case of such a regulation perhaps many women due to give birth to a potentially stateless child, would travel to the Netherlands. Another - more convincing - reason was that such a regulation would attribute Netherlands nationality to the children of stateless South-Moluccan persons, who live in the Netherlands since the occupation of the South Moluccan Republic by Indonesia in the early fifties, and who expressly do not want 
to acquire Netherlands nationality, because they are still hoping for a new independent South Moluccan Republic.

Another consequence of the aim to avoid statelessness is the provision of article 14 Nationality Act 1984, which states that Netherlands nationality is never lost, if this would cause statelessness. At the time of writing, a bill proposing an amendment of art. 14 is in the Second Chamber of Parliament. If the bill is accepted, Netherlands nationality may be lost by a Government decision, if the nationality was acquired by naturalisation or option declaration based on fraudulent information, even if such a loss of Netherlands nationality would cause statelessness.

\section{Dual nationality and naturalisation rate}

The Netherlands ratified the Strasbourg Convention on reduction of cases of multiple nationality and military obligations in cases of multiple nationality of 6 May $1963 .{ }^{5}$ Obviously, the Netherlands legislator deemed the realisation of sexual equality in the law of nationality much more important than the avoidance of plural nationality. In the Nationality Act of $\mathbf{1 9 8 4}$ the reduction of cases involving plural nationality is embodied in just five provisions (art. 9 para. 1(b) and the four paras of art. 15) and only one of these provisions was really new in comparison with the previous legislation. The Netherlands ratified the 1993 Second Protocol to the 1963 Convention, which allows some exceptions to the main principle of the Convention embodied in article 1: the loss of a nationality in case of voluntary acquisition of a foreign nationality. Because of the fact that Netherlands nationals, who also possess another nationality, are registered exclusively as Netherlands nationals, no statistical data on the amount of such dual or plural nationals are available.

A considerable number of foreigners have acquired Netherlands nationality in the recent past by declaration of option, naturalisation or adoption. The figures are as follows:

1985: 34700 ; 1990: 12800 ; 1994: 49 400; 1995: $71400 ; 1996: 82700$

The relatively high figure in 1985 can be explained by the fact that in 1985 the equal treatment of men and women was realised in Netherlands nationality law. Minor children of a foreign father and a Netherlands mother, who did not acquire the nationality of the mother before 1985, could acquire the nationality of their mother by lodging a declaration of option between 1 January 1985 and 1 January 1988 . The 
enormous increase of naturalisations between 1994 and 1997 can partly be explained by the fact that in these years naturalisation was possible without renunciation of a previous nationality.

\section{Rights of nationals and rights of aliens}

The rights of nationals differ from rights of aliens in several respects:

\section{Electoral rights}

Only Netherlands nationals may participate in the national elections (arts 4 and 56 Constitution) and in the elections on the provincial level (art. 129 Constitution). On the municipal level both citizens and (permanent) residents can participate (art. 130 Constitution and art. B 3 (Elections Act) Kieswet): the right to participate in the municipal elections is granted to all Netherlands nationals, EU citizens and, finally, all aliens residing at least five years in the Netherlands and possessing a residence permit based on articles 9 or 10 Aliens Act.

\section{Access to some (public) functions}

The Netherlands want to restrict the functions reserved for nationals as far as possible; a list with so-called 'vertrouwensfuncties' (confidence functions) reserved for nationals is published in the Staatscourant 1988, 248.

\section{Some 'financial' rights}

Although permanent residents are almost in all cases equally treated; having Netherlands nationality is often not enough in order to be entitled to certain financial benefits (rights to a pension, social benefits); very often residence is an additional requirement. See, for example, article 56 National Old Age Pensions Act (Algemene Ouderdoms Wet): "The advantages of art. 55 can exclusively be enjoyed by a person, who is Netherlands national and resides in the Netherlands.' Moreover, very often some groups of aliens and Netherlands nationals are treated equally. See, for example, article 56 National Social Assistance Act (Algemene Bijstandswet), which determines that an alien living in the Netherlands with a permit based on articles 9 or 10 Aliens Act enjoys the same rights as a Netherlands national.

\section{Other rights}

An example to the right on free choice of labour, guaranteed by article 19 para 3 of the constitution, although it has to be emphasised that this right is not really enforceable for nationals as well. 


\section{Applicability of Netherlands or foreign private law}

The application of Netherlands private law is determined by conflict rules; in some of these conflict rules the nationality of persons involved is a connecting factor.

\section{Applicability of Netherlands criminal law}

Again nationality is sometimes used as a connecting factor.

\section{Residential rights}

Restriction on freedom of entry and departure

The freedom of entry for foreigners is restricted. The possibility of entry of EU citizens is governed by EU law. Other citizens must fulfil the conditions of international treaties, for example, the convention on refugees of 1951, or of Netherlands immigration law (arts 6-10 Aliens Act). A right to enter the country may exist because of international obligations, or may exist where there is a special Netherlands interest, for example when it concerns business people or medical specialists with particular expertise. A right of residence may also be obtained on humanitarian grounds, for example reunion with family members or urgent need of medical assistance. Netherlands citizens always have the right to enter the territory.

Aliens and citizens have in principle the freedom of departure. This freedom is restricted if they are sentenced to imprisonment or a criminal action is commenced against the persons involved.

\section{Types of residential status}

The Netherlands know an enormous variation of residential status for foreigners living in the Netherlands. The main categories are:

a) Temporary stay permit for aliens, without the obligation of a visa (EU citizens and the nationals of some other countries). Maximum period of stay: three months (art. 8 Aliens Act). The person must possess valid documents for crossing the border, for example a passport. Aliens who are not nationals of a European Union or European Economic Area country must also have enough financial means to support themselves during their stay and enough money to pay for their departure from the Netherlands. EU/EEA nationals are, during their temporary stay, not eligible for state benefits, such as national assistance benefits. 
b) Temporary stay permit for aliens, with visa obligation. The visa has to be applied for at the Netherlands diplomatic representation in the country of origin or the country of residence. Maximum period of stay: three months (art. 8 Aliens Act).

c) Authorisation for temporary stay (machtiging tot voorlopig verbliff). Nationals of most countries for which a visa is required, who want to stay in the Netherlands for a period longer than three months must, in principle, have an authorisation for temporary stay. The authorisation must be requested at the Netherlands embassy or consulate in the country of origin, or the country of residence. The authorisation is a sticker which is placed inside the passport of the person involved. Within three days after arrival in the Netherlands the alien involved has to apply for a residence permit at the Aliens Police (Vreemdelingenpolitie).

d) Temporary residence permit (vergunning tot verblijf), valid for one year. A temporary residence permit must be taken each year to the Aliens Police for extension. After five years, an alien can apply for a permanent residence permit (vergunning tot vestiging).

e) Conditional temporary residence permit (voorwaardelijke vergunning tot verblijf ).

f) Permanent residence permit (vergunning tot vestiging), valid for an indefinite period (art. 10 para 1 lit. a Aliens Act).

g) Admission as a refugee (so-called A-status under art. 15 Aliens Act); valid for an indefinite period (art. 10 para. 1 lit. b); no time limit is attached to this status.

h) Permit for residence on humanitarian grounds, granted because of individual circumstances; valid for one year, but may be extended (art. 9, 12a Aliens Act). After five years they can apply for a permanent residence permit. They are allowed to work.

i) Provisional temporary residence permit (art. 12b Aliens Act); given to asylum seekers who did not receive refugee status or a residence permit on humanitarian grounds, but whose compulsory expulsion is not possible because of the situation in the country of origin. When the situation in their country of origin improves, these asylum seekers can be sent back to their home countries. If the situation does not improve within three years, they can receive a normal temporary residence permit. During the first year of residence these persons are only allowed to take temporary jobs; during the second year they can take vocational courses in addition to temporary jobs. In their third year they can allowed to work without restrictions. A provisional temporary residence 
permit is valid for one year, but may be extended twice with one year.

If an alien lives in the Netherlands on any permit for a period of three years, in principle a normal temporary residence permit is granted. After a period of residence of at least five years application may be made for a permanent residence permit. After the same period of residence, five years, an application for naturalisation is possible (art. 8 Nationality Act).

Except for the already-mentioned residence requirement of five years, the alien who applies for a permanent residential status must fulfil the following requirements:

1 he must have sufficient assets, and

2 he must not constitute serious danger to national security (art. 13 para. 3 Aliens Act).

If a permanent resident moves his main habitual residence to another country, he loses his permanent residence status in the Netherlands (art. 14 para 2 Aliens Act). It is not always clear whether a person has already moved his main habitual residence. If a person stays abroad for an uninterrupted period of nine months within one year, he is deemed to have moved his main habitual residence to another country. ${ }^{6}$

It follows already from the previous paragraphs that citizens of other Member States of the European Union have a better residence position in the Netherlands than other aliens. The same applies for nationals of the Member States of the European Economic Area. Citizens of States with an Association Treaty with the European Union are also privileged, if they want to work in the Netherlands independently. The citizens of Belgium and Luxembourg are immediately entitled to a permanent residence permit (without the condition of five years of residence and without the requirement of sufficient assets). This privileged position is based on the Benelux Treaty. The citizen of Indonesia and Suriname (former possessions of the Netherlands) no longes have a privileged position.

The Netherlands do not have particular problems with the alien registration procedure. Aliens can be requested by the border control authorities to provide fingerprinting and to be photographed (art. 65 Aliens Decree). 


\section{Social rights}

Some social rights differ for citizens and aliens, but it has to be mentioned that often citizens only enjoy certain social rights if they are residing in the Netherlands, and that often aliens residing in the Netherlands enjoy the same social rights as citizens. The principle formulated above applies in particular to the national pension system.

Not all aliens residing in the Netherlands can ask for social assistance if they do not have enough money to support themselves. Aliens having a temporary residence permit are often not entitled to social assistance.

Illegal aliens (i.e. persons who reside illegally in the Netherlands) are excluded from the use of public facilities, with the exception (in certain circumstances) of education, health care and legal assistance. In order to enforce this exclusion the databases of the institutions involved are linked with each other and with the databases of the immigration authorities.

The Netherlands do not have a special war-related compensation scheme for alien residents in the Netherlands. It may theoretically happen that foreigners are entitled to war-related compensation, but the number of such persons will be negligible.

The children of some groups of aliens living in the Netherlands have a right to follow some lessons in the language of their parents during their primary and secondary school education.

\section{Economic rights}

The Netherlands does not limit property rights for aliens.

If an alien has a residence permit for the Netherlands and has a labour permit, in principle there are no limitations to the right of self-employment. As already mentioned above, no 'vertrouwensfuncties' (confidence functions) can be fulfilled by aliens.

Limitations do apply to work according to status. The right to work is very restricted for asylum seekers (see above).

As already mentioned above only a very restricted number of socalled 'vertrouwensfuncties' (confidence functions) are reserved for nationals. Therefore an alien can be appointed as, for example, university professor, doctor, nurse, or civil servant of a ministry, province or municipality. The reason for reserving some functions for nationals is normally because of national sovereignty, and in some cases national security. 
Aliens may not join the Netherlands police force. The reason for reserving this function for nationals is the exercise of public authority.

No statistical data are available on the amount of aliens working in governmental posts.

An EU citizen may be appointed as a government official under the same conditions as a Netherlands national. EU citizens are only excluded from the so-called 'vertrouwensfuncties' (confidence functions). Other aliens may be appointed as government officials, if they have a labour permit. If an alien does not have a labour permit, such a permit will only be given, and therefore the person involved can only be appointed, if no qualified EU citizen can be found for the job concerned.

\section{Political rights}

As already mentioned above, aliens can participate in municipal elections, but do not have electoral rights for the national parliament or provincial parliaments. The reason that they are excluded is national sovereignty. There is, however, a bill in parliament proposing to grant the right of participation in the elections of the provincial parliaments to aliens residing in the Netherlands.

Requirements for aliens in order to participate in elections on municipal level are set as above. No official statistics are published regarding the turn-out of aliens at municipal elections of (i.e. those living in the Netherlands for at least five years or being EU citizens); and no official statistics are published regarding the elected foreign members of municipal councils.

There is no obligation to vote on persons who have the right to vote. In the past an obligation to vote did exist, but this was abrogated some 25 years ago.

Is it true that the Netherlands do not make a distinction between a right to vote and a right to stand in respect of the participation of aliens in the elections on municipal level? Compare Article B 3 Elections Act mentioned above at p. 40 with art. 10 of the Statute on Municipalities. In this context it has to be mentioned that, unlike some other states, the mayors of municipalities are not elected, but directly appointed by the Queen on proposal by the Minister of Internal Affairs. The position of a mayor is classified as a 'vertrouwensfunctie' and therefore reserved for Netherlands nationals.

The political freedoms are not restricted for aliens. Restrictions would violate the Constitution, in particular article 7-9. 


\section{Notes}

1 Source of the statistical information in this paragraph: Statistisch Jaarboek 1998 (Centraal Bureau voor de Statistiek: Voorburg/Heerlen, 1998).

2 It has to be mentioned that the Indonesian community in the Netherlands has lived there for almost fifty years. Most children born within this community have as Indonesian parents persons who themselves were born in the territory of the Netherlands. Therefore most new born children acquire at birth Netherlands nationality as a consequence of the provision of art. 3 para. 3 Nationality Act. They are no longer counted in Netherlands statistics as Indonesian citizens.

3 UNTS, Bd. 989, 175; Tractatenblad 1967, 124.

4 Tractatenblad 1974, 32 .

5 UNTS Bd. 634, 221; Tractatenblad 1964, 4; ETS, No. 43.

6 Aldo Kuijer/Hanneke (J.D.M.) Steenbergen, Nederlands vreemdelingenrecht, 4th edn (Nederlands: Centrum voor Buitenlanders, 1999), pp. 194, 195. 